\title{
ANALISIS PENGELOLAAN SUMBER DAYA ALAM SEBAGAI SUMBER PENDAPATAN EKONOMI MASYARAKAT LOKAL DI SEMPADAN SUNGAI RUNGAN KOTA PALANGKA RAYA
}

\section{Analysis of natural resource management as a source of economic income of local people at the boundary of Rungan City Palangka Raya River}

\section{Nova Riyanti \\ M.Riban Satia \\ Muh Azhari}

Universitas Muhammadiyah Palangkaraya, Palangka Raya, Central Kalimantan, Indonesia

email:riyantinv@gmail.com

Kata Kunci:

Pengelolaan

Sumber Daya Alam

Pendapatan

Ekonomi

Masyarakat Lokal

Keywords:

Management

Natural Resources

Income

Economic

Local communities

\begin{abstract}
Abstrak
Penelitian ini bertujuan untuk menganalisis pengelolaan sumber daya alam sebagai sumber daya sebagai sumber pendapatan ekonomi masyarakat lokal di sempadan sungai rungan Kota Palangka Raya. Mengingat selama ini masyarakat lokal hanya bergantung dengan sumber daya perikanan saja,sedangkan sumber daya perikanan sekarang sudah sulit dicari disebabkan berbagai pencemaran yang terjadi.
\end{abstract}

Pendekatan penelitian dalam penelitian ini berjenis deskriptif kualitatif yang bertujuan menggambarkan tentang kompleksitas dan kedinamisaan pengelolaan sumber daya alam untuk sumber pendapatan ekonomi masyarakat lokal. Pengumpulan data dalam penelitian ini peneliti menggunakan teknik studi lapangan (field research) yaitu teknik pengumpulan data yang dilakukan dengan cara peneliti terjun secara langsung ke lapangan tempat lokasi penelitian dilakukan. Teknik Pengumpulan data yang digunakan yaitu observasi, wawancara, dokumentasi, dan studi literatur.

Hasil Penelitian menunjukkan kesimpulan bahwa selama ini, pengelolaan potensi sumber daya alam yang tersedia belum dikelola dengan baik. Sehingga sumber daya alam yang belum terkelola tersebut tidak dapat memberikan sumber pendapatan ekonomi yang tetap bagi masyarakat lokal di sempadan sungai rungan Kota Palangka Raya. Padahal berbagai potensi dapat dikembangkan untuk sumber pendapatan ekonomi masyarakat lokal seperti tanaman dan tumbuhan yang dapat dibudidayakan serta memiliki kearifan lokal untuk dijadikan wisata religi yang dapat menjadi sumber pendapatan ekonomi masyarakat lokal. Faktor penghambat pengelolaan sumber daya alam untuk sumber pendapatan ekonomi masyarakat lokal di Sempadan Sungai Rungan Kota Palangka Raya yaitu I) kepemilikan pribadi atau penguasaan lahan, 2)Dari sisi Kelembagaan dan sisi Non Kelembagaan. 3)Tidak ada dukungan dan pemanfaatan teknologi dalam pengelolaan sumber daya alam untuk sumber pendapatan ekonomi masyarakat lokal.

\section{Abstract}

This research aims to analyze the management of natural resources as a resource as a source of economic income of local communities on the border of the river Rungan Palangka Raya City. As long as this local community relies only on fishery resources, while fishery resources are now difficult to find due to various pollution that occurs.

The research approach in this research is a qualitative descriptive that aims to illustrate the complexity and dynamism of natural resources management for the local community's economic income. Data collection In this research researchers use field research techniques that are data collection techniques conducted using researchers plunge directly into the field where the research location is conducted. The data collection techniques used are observations, interviews, documentation, and literature studies.

The results showed research conclusions that during this time, the management of potential natural resources available has not been well managed. So that the unmanaged natural resources are not able to provide a permanent source of economic income for local communities on the border of the city of Palangka Raya River. Whereas various potentials can be developed for the source of economic income of local people such as plants and plants that can be cultivated and have local wisdom to be religious tourism that can be a source of economic income of local people. The barriers to natural resource management for the source of economic income of local communities on the boundary of the Rungan River of Palangka Raya City are I) personal ownership or land tenure, 2)from the institutional and Non-institutional side. 3) No support and utilization of technology in the management of natural resources for the source of economic income of local communities. 


\section{PENDAHULUAN}

Lingkungan sangat penting bagi kehidupan makhluk hidup mengingat lingkungan menjadi daya dukung kehidupan. Saat ini negara-negara maju di dunia menyoroti dan membuat agenda pembangunan yang berkelanjutan sebagai pembangunan baru yang mengakomodasi semua perubahan terutama berkaitan dengan situasi dunia mengenai isu penipisan sumber daya alam, perubahan iklim dan kerusakan lingkungan. Krisis lingkungan yang sedang dialami seluruh dunia membawa keinginan untuk keseimbangan lingkungan hidup yang terjaga. Lingkungan hidup yang diharapkan dapat berlanjut terus-terus sehingga kekayaan alam tersebut juga dapat dinikmati oleh generasi-generasi yang akan datang.

Di negara-negara berkembang, memerangi permasalahan lingkungan masih belum terlalu nampak dikemukakan. Mengingat di negara berkembang masih memiliki sumber daya alam yang melimpah dengan ditandai masih banyaknnya hutan lindung, hutan tropis dan kekayaan alam lainnya. Sama halnya yang terjadi di Indonesia, topik masalah lingkungan hidup masih kurang dipedulikan.

Masalah-masalah lingkungan sudah terjadi disegala lini sehingga diperlukannya pelestarian lingkungan untuk menjaga keberlanjutan sumber daya alam yang dimiliki agar nantinya bisa terjaga dan dapat dinikmati sampai generasi ke generasi. Begitu kursialnya permasalahan lingkungan diberbagai negara maju, mengingat negara-negera maju sudah tidak memiliki sumber daya alam yang alami. Sumber daya alam yang mereka miliki hanya buatan saja. Padahal, disisi lain indonesia masih memiliki banyak sumber daya alam yang berlimpah, sehingga indonesia hanya perlu menjaga yang sudah dimilikinya. Kekayaan alam yang dimiliki indonesia akan bertahan lama jika dikelola dengan baik oleh berbagai pemangku kepentingan.

Indonesia memiliki pulau Kalimantan yang dijuluki paru-paru dunia oleh amerika serikat dan singapura, mengingat pulau Kalimantan masih memiliki hutan alami sebagai hutan yang harus dilindungi karena fungsinya sebagai penyangga paru-paru dunia. Disisi lain, Kalimantan juga dalam bahasa lokal adalah pulau yang memiliki banyak sungai (Kali= Sungai, Mantan=Banyak). Itu sebabnya Kalimantan juga dikenal dengan julukan 'pulau seribu sungai'. Dimana penduduk asli Kalimantan adalah masyarakat lokal yang dikenal masyarakat dayak yang memiliki kebergantungan dengan sumber daya alam terutama hutan dan sungai.

Provinsi Kalimantan Tengah telah dinobatkan sebagai ibukota paru-paru dunia oleh Komite Perdamaian Dunia saat rapat koordinasi tingkat provinisi lintas program lintas sektor tahun 2018 lalu. Predikat ibu kota paru-paru dunia diberikan karena hutan Kalimantan Tengah dikenal menyediakan udara sejuk bagi masyarakat dunia sepanjang masa. Deklarasi itu membuat rasa bangga bagi pemerintah dan masyarakat. Namun kebanggaan tidak bisa hanya sekedar memegang predikat tapi yang lebih berat dari itu adalah tanggung jawab untuk mempertahankannya.

Masyarakat lokal di Kalimantan Tengah telah memiliki konsepsi terhadap hutan. Pandangan masyarakat lokal, hutan merupakan komponen lingkungan yang sangat penting bagi kehidupan. Selain sebagai rumah, hutan juga berfungsi sebagai penyangga sistem kehidupan untuk memulihkan 
kesuburan tanah pada sistem perladangan gilir balik dan untuk perlindungan tata air, terutama kelestarian sungai. Mengingat sungai sangat penting keberadaanya sebagai urat nadi mobilitas mereka. Namun kini, sudah banyak kemunduran dengan ketidak pedulian masyarakat dengan sungai. Sungai tidak lagi difungsikan sebagai transportasi utama, mengingat pembangunan jalan sudah membuka akses bagi kehidupan masyarakat.

Pemerintah Kota Palangka Raya sebagai Ibukota Provinsi Kalimantan Tengah telah berupaya melindungi ekosistem sungai dan danau dengan menerapkan konsep "sabuk hijau" (green belt) yang mencakup penataan bangunan ditepi sungai dan danau. Konsep green belt ini sebagai upaya pemerintah kota menjaga Kawasan sungai dan danau dari eksplorasi dan berbagai tindakan yang tidak bertangung jawab. Konsep tersebut juga sudah dikuatkan dengan adanya payung hukum berupa peraturan wali kota sebagai upaya kelestarian sungai agar tidak disalahgunakan.

Salah satu penerapan konsep green belt ialah melalui program pemberdayaan masyarakat di Kawasan sungai dan danau. Program pemberdayaan tersebut melihatkan masyarakat pinggiran sungai pada program ternak lebah dan ternak ikan. Lebih lanjut, konsep sabuk hijau tersebut juga tidak memperkenakan mendirikan bangunan permanen dengan radius 500 meter dari sungai. Namun untuk bangunan yang sudah ada tidak ada penggusuran.

Pemerintah Kota Palangka Raya saat ini juga memiliki visi melalui konsep lingkungan cerdas, masyarakat cerdas dan ekonomi cerdas. Konsep tersebut juga sudah sepantasnnya menjadi salah satu langkah untuk pemerintah kota yang menjadi aktor pelestarian lingkungan untuk mengambil bagian dalam memecahkan persoalan lingkungan. Persoalan lingkungan tersebut, terutama lingkungan sungai yang memiliki keunikan dan fungsi yang melekat kuat dengan lingkungan masyarakat dan ekonomi masyarakat sekitar.

Sungai rungan merupakan salah satu cabang sungai Kahayan di Kota Palangka Raya. Sungai rungan memiliki keterkaitan erat dengan kondisi masyarakat lokal yang tinggal di sekitarnya. Keberadaan masyarakat yang tinggal di daratan sungai rungan Kota Palangka Raya sudah ada sejak dahulu sebelum kota terbentuk. Sejak dulu, Masyarakat petuk ketimpun, marang, sampai rakumpit sebagian besar masih bergantung dengan sungai rungan. Sehingga konsep green belt serta konsep lingkungan cedas, masyarakat cedas dan ekonomi cerdas tersebut menjadi benteng masyarakat sekitar untuk tidak disalahkan ketika tragedy of the common terjadi di sekitar sungai rungan.

Selama ini, masyarakat lokal mengantungkan kehidupan mereka pada sumber daya ikan yang ada di sungai rungan. Namun sumber daya ikan tidak bisa lagi menjadi sumber daya ekonomi utama masyarakat lokal. Hal ini mengingat sulitnya mencari ikan akibat dari sebagai aktifitas yang mencemari lingkungan sungai seperti penambangan liar (illegal mining) dan hadirnya perusahanan perkebunan sebagai tragedy of the common sumber daya ikan. Selain itu, ketika terjadi penurunan harga karet, rotan dan sawit maka usaha lokal masyarakat juga terganggu sehingga sebagian masyarakat lokal memilih beralih melakukan penambangan emas liar (illegal mining) untuk mendapatkan pendapatan. 
Saat ini, kondisi sungai rungan mengalami penurunan kualitas air yang terlihat dari kondisi air yang semakin kotor, keruh dan berwarna kekuningan. Penurunan kualitas air tersebut disebabkan salah satunya praktik penambangan emas tanpa ijin (illegal mining) yang terjadi di kawasan sungai yang membuat sungai tercemar. Sehingga potensi sumber daya ikan dari waktu ke waktu menurun, sementara upaya dari pelestarian ikan bisa dikatakan tidak dilakukan. Hal ini mengingat upaya yang dilakukan seperti restrocking tidak sebanding dengan ekploitasi yang dilakukan. Kemudian, pencegahan yang dilakukan untuk mempertahankan sumber daya ikan dengan melakukan pengawasan penggunaan alat tangkap ikan yang tidak ramah lingkungan juga sangat sulit dilakukan. Sehingga perlu melihat potensi selain sumber daya ikan untuk menopang sumber daya ekonomi masyarakat lokal.

Mencermati kondisi lingkungan sungai rungan saat ini. Harus disadari, bahwa masyarakat lokal tidak bisa terfokus dengan potensi sumber daya ikan yang ada saja. Masyarakat lokal tidak mungkin bergantungan hidup dengan keberadaan ikan sepanjang tahun apalagi dengan kondisi sumber daya alam yang tercemar sudah mengganggu sumber daya ikan. Maka masyarakat lokal perlu melakukan Pelestarian lingkungan di sempadan sungai rungan. Pengelolaan lingkungan di sempadan sungai rungan itu tidak hanya menjadi upaya pencegahan kerusakan lingkungan saja tapi bisa memberikan sumber daya ekonomi bagi masyarakat lokal.

Masyarakat lokal yang tinggal di sempadan sungai rungan memiliki berbagai potensi alam dan potensi kearifan lokal dalam menjaga kelestarian lingkungan sungai. Potensi tanaman lokal seperti rotan, jamur, pakis dan tanaman alami yang dapat dikonsumsi bisa diberdayakan untuk pendapatan ekonomi masyarakat. Kemudian, tanaman obat yang seperti bajakah yang mudah tumbuh di sempadan sungai rungan bisa menjadi nilai ekonomis bagi masyarakat lokal. Lebih lanjut, potensi lain seperti lebah madu yang bisa di pasang di pohon-pohon di pinggiran sungai juga dapat memberikan pemasukan bagi masyarakat lokal. Meski demikian, masyarakat lokal juga bisa tetap melakukan pengkapan ikan dengan ramah lingkungan seperti penggunaan beje.

Berbagai potensi sumber daya alam dan kearifan lokal yang dapat dikelola bisa memberikan dampak ekonomi masyarakat lokal yang ada di Sempadan Sungai Rungan. Sehingga dalam hal ini peneliti tertarik meneliti da rumusan masalah dalam penelitian ini yaitu :

I. Bagaimana potensi sumber daya alam yang tersedia dapat dikelola untuk sumber pendapatan ekonomi masyarakat lokal di Sempadan Sungai Rungan Kota Palangka Raya?

2. Bagaimana faktor penghambat pengelolaan sumber daya alam untuk sumber pendapatan ekonomi masyarakat lokal di Sempadan Sungai Rungan Kota Palangka Raya?

\section{TINJAUAN PUSTAKA}

Pengelolaan dapat diartikan sebagai upaya melakukan sesuatu agar lebih sesuai serta cocok dengan kebutuhan sehingga dapat lebih bermanfaat. Begitu pula menurut Atmosudirdjo (Dadie,2019) Pengelolaan merupakan kegiatan pemanfaatan dan pengendalian atas semua sumber 
daya yang diperlukan untuk mencapai ataupun ,menyelesaikan tujuan tertentu.

Namun disisi lain, Kata "Pengelolaan" sering kali disamakan dengan manajemen, yang berarti pula pengaturan atau pengurusan (Sarnoto, 20I3). Banyak yang mengartikan manajemen sebagai pengaturan, pengelolaan, dan pengadministrasian, dan memang itulah pengertian yang populer saat ini. Pengelolaan diartikan sebagai suatu rangkaian pekerjaan atau usaha yang dilakukan oleh sekelompok orang untuk melakukan serangkaian kerja dalam mencapai tujan tertentu. Sehingga 4 indikator manajemen disama artikan dengan pengelolaan yaitu:

I. Perencanaan (planning)

2. Pengorganisasian (organizing)

3. Pengarahan (directing)

4. Pengawasan (controlling)

Meski demikian,pendapat Putuhene (2019) yang mengungkapkan secara umum, pengelolaan sumber daya alam yang berkelanjutan paling sedikit harus memenuhi indikator lestari dan keberlanjutan dibawah ini :

I. Pengelolaan yang mampu mendukung produktivitas optimal bagi kepentingan kehidupan (indikator ekonomi)

2. Pengelolaan yang mampu memberikan manfaat merata bagi kepentingan kehidupan (indikator sosial)

3. Pengelolaan yang memampu mempertahankan kondisi lingkungan dari degradasi (indikator lingkungan)

4. Pengelolaan dengan menggunakan teknologi yang mampu dilaksanakan oleh kondisi penghidupan setempat sehingga dapat merangsang tumbuhnya sistem intitusi pendukung (indikator teknologi).

Dengan demikian, dalam penelitian ini peneliti menggunakan pendapat dari Putuhene (2019) mengenai pengelolaan sumber daya alam yang berkelanjutan. $\mathrm{Hal}$ ini mengingat 4 indikator tersebut berkaitan erat dengan topik yang akan diteliti.

\section{METODOLOGI}

Penelitian ini berjenis deksriftif kualitatif yang bertujuan menggambarkan tentang kompleksitas dan kedinamisaan pengelolaan sumber daya alam untuk sumber pendapatan ekonomi masyarakat lokal. Lokasi penelitian ini berada di Sempadan Sungai Rungan Kota Palangka Raya. Lokasi ini dipilih dengan pertimbangan bahwa Sungai Rungan menjadi yang sangat penting untuk dijaga dari permasalahan degradasi lingkungan yang beberapa dekade ini terjadi dan masih banyak potensi sumber daya alam yang bisa memberikan sumber pendapatan bagi masyarakat lokal. Sungai Rungan juga melintasi beberapa pemukiman masyarakat lokal yang membentang dari hulu ke hilir melewati beberapa Kelurahan dalam 3 Kecamatan Di Kota Palangka Raya.

Pengumpulan data dalam penelitian ini peneliti menggunakan teknik studi lapangan (field research) yaitu teknik pengumpulan data yang dilakukan dengan cara peneliti terjun secara langsung ke lapangan tempat lokasi penelitian dilakukan. Teknik Pengumpulan data yang digunakan yaitu observasi, wawancara, dokumentasi, dan studi literatur. 


\section{HASIL DAN PEMBAHASAN}

Masyarakat lokal yang tinggal di sekitar sungai memiliki ketergantungan terhadap pemanfaatan sungai dan sumber daya alam yang ada disekitarnya. Mata pencaharian masyarakat di hulu sungai rungan yang berada di kelurahan petuk Bukit, Kecamatan Rakumpit adalah Nelayan Ikan, Penyadap Karet, Berladang dan Berkebun yang dijadikan pekerjaan musiman masyarakat sekitar. Kemudian, masyarakat kelurahan Marang, Kecamatan Bukit Batu yang mewakili sungai rungan memiliki mata pencaharian utamanya adalah nelayan dan beternak. Cara masyarakat menjaga keseimbangan sungai dengan mencari ikan dengan menggunakan penggunaan alat tradisional seperti rengge, kelamban, selamba, rempa, melunta jika air surut dan keramba.

Masyarakat kelurahan Petuk Katimpun, Kecamatan Jekan Raya yang mewakili bagian hilir sungai rungan memiliki mata pencaharian sebagai nelayan dan berkebun. Sedangkan masyarakat kelurahan Tumbang Rungan, Kecamatan Pahandut yang tinggal di muara hilir sungai rungan memiliki mata pencaharian sebagai petani dan pekerja lepas. Sehingga dari data mata pencaharian tersebut dapat disimpulkan pada tabel berikut :

Dimana secara umum, masyarakat disekitar sempadan sungai rungan memiliki mata pencaharian sebagai nelayan. Mata Pencaharian pokok masyarakat yang dominan tergantung terhadap alam,didorong oleh kondisi ekosistem yang baik. Hutan primer yang membentang sepanjang sungai rungan di Kota Palangka Raya pada tempo lalu serta kondisi objektif air sungai yang bersih memberikan ruang kehidupan untuk hampir semua jenis ikan air tawar. Kualitas air sungai yang bersih juga memberikan sejuta manfaat untuk kehidupan masyarakat, bahkan dulu masyarakat lokal bisa langsung mengkonsumsi air sungai secara langsung. Hal tersebut diungkapkan oleh tokoh masyarakat sebagai berikut :

"Sungai Rungan ini menjadi kekyaaan sumber daya alam yang sangat luar biasa bagi kami (Masyarakat lokal), semua kebutuhan seharihari kami dipenuhi oleh sumber daya alam yang ada di sekitar sungai. Kami tidak perlu berpikir untuk makan karena sumber daya alam telah memberikan kesediaan yang melimpah. Ikan mudah didapatkan, tumbuhan dan sayur ada disekitar rumah, bahkan hampir 7-10 tahun lalu kami bisa meminum air sungai secara langsung karena airnnya jernih dan bersih".

Namun kini keadaan sumber daya alam yang ada di sungai rungan di Kota Palangka Raya tidak lagi seperti dulu. Pengamatan ini peneliti lakukan sepanjang Sungai Rungan. Kondisi air yang dulu bersih sekarang menjadi keruh, berwarna kuning seperli air lumpur. Keadaan sungai rungan yang ada di kelurahan marang bisa menjadi contoh, seperti gambar dibawah ini :

Gambar.I

Kondisi Air Sungai Rungan

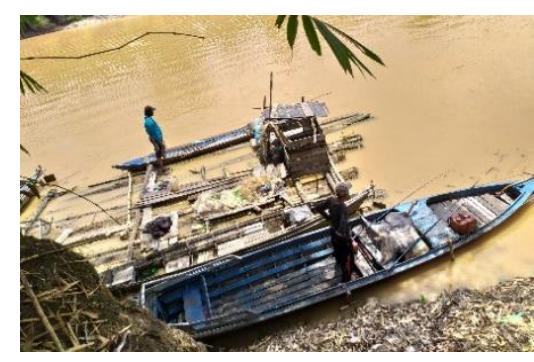

Perubahan warna air itu terjadi karena ada aktifitas penambangan yang ada dari Hulu Sungai Rungan sampai Hilir Sungai Rungan sehingga membawa aliran ke sungai kahayan dan beberapa danau sekitar sungai rungan. Namun air keruh itu juga dampak dari maraknnya penambang emas dan pasir yang airnya mengalir dari Kabupaten tetangga 
seperti Kabupaten Gunung mas dan Kabupaten Pulang Pisau.

Setelah mengetahui adanya para penambang di sepanjang sungai rungan, dari berbagai sumber peneliti menemukan bahwa keberadaan para penambang emas yang ada di sepanjang sungai rungan sifatnnya illegal atau tak berijin. Namun masyarakat juga mengetahui hal itu, masih belum jelas mengapa aktifitas tambang tak berijin itu terus berjalan. Tetapi dari penungkapan beberapa informan mengatakan bahwa kegiatan itu terjadi sejak masyarakat tidak dapat lagi berladang. Kebiasaan masyarakat yang membuka lahan dengan cara dibakar telah dinyatakan sebagai pelanggaran hukum. Sehingga produk kebijakan itulah yang membuat sebagian masyarakat juga ikut beralih profesi sebagai penambang emas untuk memenuhi kebutuhan sehari-hari. Kemudian, $\mathrm{Hal}$ tersebut juga dilakukan saat harga sawit, karet dan rotan yang turun.

Meski Demikian, Penelitian ini akan berfokus kepada potensi sumber daya alam yang ada di sempadan sungai rungan, peneliti lebih lanjut ingin mengetahui pengelolaan sumber daya alam dari setiap indikator, sebagai berikut :

I. Pengelolaan yang mampu mendukung produktivitas optimal bagi kepentingan kehidupan (indikator ekonomi)

Indikator yang pertama ini adalah dari sisi ekonomi. Selama ini masyarakat bergantung pada sumber daya alam perikan dan sumber daya alam lainnya seperti sawit, karet dan rotan. Namun suber daya alam tersebut tidak dapat memberikan nilai pendapatan yang tetap bagi masyarakat lokal.
Apalagi saat harga sawit, karet dan rotan yang harga jualnya menurun.

Jika diamati lebih dalam, sumber daya alam yang ada itu hanya sebagian dari potensi yang dimanfaatkan oleh masyarakat lokal. Masih banyak hal yang dapat dimanfaatkan oleh masyarkat lokal sebagai nilai ekonomis yang dapat dikelola secara berkelanjutan. Sumber alam lainnya yang peneliti lakukan melalui observasi, ada tanaman pakis dan jamur yang bisa dikonsumsi dan menjadi sumber pendapatan oleh masyarakat lokal yang banyak tumbuh di pinggiran sungai. Kemudian, ada tanaman obat seperti bajakah yang tumbuh liar di sekitar sempadan sungai rungan yang saat ini sangat populer dan dapat dimanfaatkan untuk obat tradisional yang bisa menjadi sumber pendapatan tambahan bagi masyarakat lokal.

Selain itu, potensi sumber daya alam seperti ternak lebah juga bisa menjadi potensi sumber pendapatan bagi masyarakat lokal. Mengingat sepanjang sungai rungan masih terdapat pohon-pohon dan tanaman berbunga yang memiliki potensi besar untuk membudidayakan lebah alami. Meski demikian, masyrakat lokal juga tetap bisa melakukan pengkapan ikan dengan penggunaan beje yaitu kolam alamiah yang terbantuk di tengah-tengah hutan/perkebunan sebagai alat tangkap yang tradisional dan ramah lingkungan yang dapat dipasang saat air pasang, sehingga saat air surut ikan akan terkurung didalam beje tersebut. 
2. Pengelolaan yang mampu memberikan manfaat merata bagi kepentingan kehidupan (indikator sosial)

Indikator yang kedua ini adalah dari sisi sosial.Peneliti ingin mengulas dengan mengajukan pertanyaan, Apakah ada bentuk kegiatan masyarakat yang mengelola sumber daya alam secara bersama?

"Selama ini tidak ada pengelolaan sumber daya alam secara bersama. Upaya dalam pengelolaan lingkungan hanya kesadaran dari setiap individu saja. Karena setiap lahan, ada tuannya. Jadi tangung jawab masing-masing"

Dari ungkapan tersebut, memberikan gambaran bahwa ada ketidakpedulian untuk mengelola sumber daya alam secara bersamaan. Mengingat setiap jengkal lahan yang ada di sempadan sungai sudah ada kepemilikan masing-masing orang. Namun dari pengamatan mendalam yang peneliti lakukan, bahwa lahan yang ada disempadan sungai rungan masih banyak yang tidak dikelola. Hal yang menjadi temuan penting dalam indikator ini adalah banyak lahan yang tidak dikelola tersebut bukan dimiliki masyarakat lokal tapi kepemilikan oleh orang yang menginvestasikan tanahnya dan tinggal jauh dari sempadan sungai. Sehingga sumber daya alam yang ada tidak dapat memberikan manfaat ekonomi yang merata dan bahkan merugikan bagi masyarakat lokal.

Lebih lanjut, peneliti ingin lebih mendalam mengetahui keterlibatan pihak lain dalam pengelolaan sumber daya alam yang ada di sempadan sungai rungan. Hal ini dianalisa dari Kelembagaan yang terlibat dalam pengelolaan dalam sumber daya alam di sempadan sungai rungan.

Dari literatur review, Satia (2016) mengungkapkan Organisasi yang terdapat di masyarakat lokal terbagi atas dua jenis yaitu sistem budaya dan sistem pemerintahan. Organisasi kemasyarakatan yang berasal dari sistem budaya adalah Damang dan mantir dan suprastuktur diatasnya, sedangan yang berasal dari pemerintah adalah Rukun Tetangga (RT) dan Rukun Warga (RW) yang tergambar sebagai berikut :

\section{Gambar.2}

Organiasai kemasyarakatan masyarakat lokal

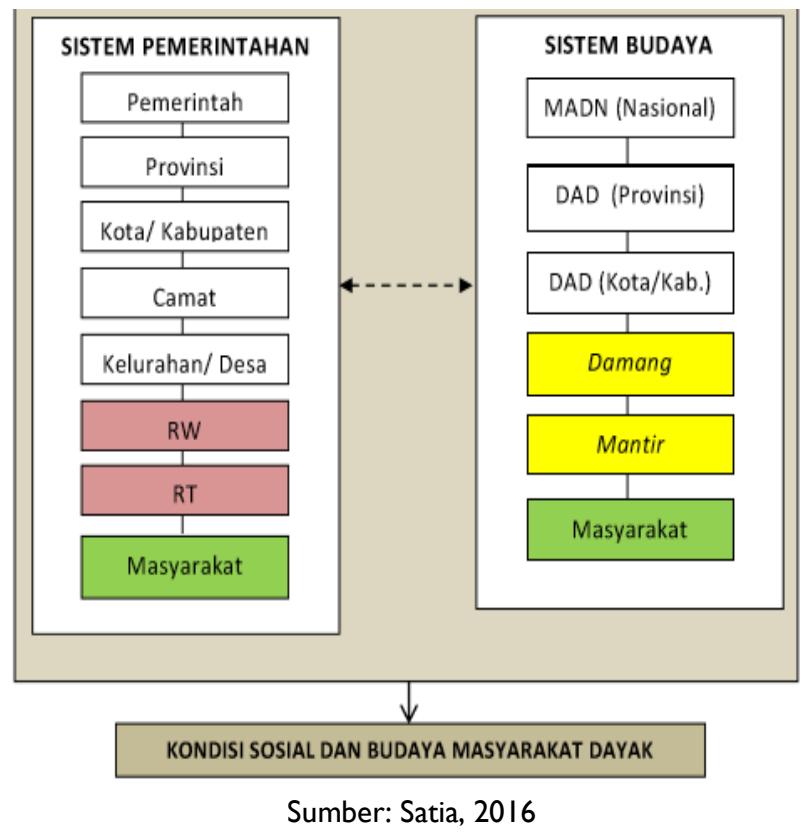

Meski demikian, pengelolaan sumber daya alam melibatkan 3 aktor penting yaitu Masyarakat, Pemerintah dan Swasta. Keberadaan ke tiga aktor tersebut, selama ini kurang maksimal dalam pengelolaan sumber daya alam yang baik. Bahkan ketiga aktor tersebut terindikasi membentuk sebuah kelembagaan yang tidak ideal. Mengingat ketiganya saling bekerjasama untuk 
mengekploitasi sumber daya alam tanpa terkendali.

Namun lebih lanjut, peneliti ingin mengetahui apakah ada program dari pemerintah daerah Kota Palangka Raya dalam menjaga sumber daya alam yang memberdayakan masyarakat lokal?

Ada beberapa informan yang mengungkapkan saat wawancara mengenai program yang diterima oleh masyarakat yaitu :

"Ada program dari pemerintah untuk masyarakat yang disaluran seperti beras sejahtera dan bantuan sosial bagi masyarakat yang kurang mampu atau masyarakat ekonomi kebawah".

Dalam penyataan tersebut memang tidak menjawab mengenai program pengelolaan sumber daya alam secara langsung, namun hal ini menjadi sorotan peneliti dan melakukan pengamatan terkait ungkapan yang disampaikan. Bahwa masyarakat lokal mendapatkan program-program pemerintah untuk membantu masyarakat kalangan kebawah untuk menopang kehidupan seharihari mereka. Namun dari bantuan tersebut masyarakat tidak bisa memiliki ketergantungan dan pemerintahpun tidak dapat memberikan bantuan itu terus-menerus. Mengingat pemberian bantuan tersebut tidak selamanya diberikan. Bantuan-bantuan hendaknya menjadi simulun bagi masyarakat lokal yang bisa dimanfaatkan untuk jangka panjang kehidupan masyarakat.

Pemerintah Kota Palangka Raya sebagai aktor penting dalam pengelolaan telah berupaya melindungi ekosistem sungai dan danau dengan menerapkan konsep "sabuk hijau" (green belt) yang mencakup penataan bangunan ditepi sungai dan danau. Konsep green belt ini sebagai upaya pemerintah kota menjaga Kawasan sungai dan danau dari eksplorasi dan berbagai tindakan yang tidak bertangung jawab. Konsep tersebut juga sudah dikuatkan dengan adanya payung hukum berupa peraturan wali kota sebagai upaya kelestarian sungai agar tidak disalahgunakan.

Dalam hal tersebut, pemerintah mendorong pemberdayaan masyarakat untuk memberikan pendapatan dari pemanfaat sumber daya alam yang tanpa merusak dan mencemari lingkungan. $\mathrm{Hal}$ ini mengingat masih ada praktik tambang liar yang masih dilakukan maka pemerintah berkeinginan melakukan pergeseran aktivitas tersebut ke pemberdayaan masyarakat. Pemberdayaan masyrakat tersebut diterapkan dari konsep green bellt untuk mengembangkan pekerjaan masyarakat lokal untuk beternak lebah atau ternak ikan sebagai sumber pendapatan masyarakat lokal.

Selain program yang telah dilakukan mengenai pemberdayaan lebah dan ternak ikan tersebut, pemerintah kota saat ini harus lebih berinovasi mencari berbagai solusi pemberdayaan lain yang dapat memberikan sumber pendapatan yang tetap bagi masyarakat lokal. Hal ini juga berkorelasi dengan bantuanbantuan yang selama ini dilakukan. Hendaknya ada program yang memberikan kemandirian bagi masyarakat lokal seperti budidaya bajakah dan memikirkan disitribusi tanaman obat tersebut untuk memberikan dampak ekonomi bagi masyarakat setempat. 
3. Pengelolaan yang memampu mempertahankan kondisi lingkungan dari degradasi (indikator lingkungan)

Indikator yang ketiga ini adalah dari sisi lingkungan, Selama ini ada kegiatan masyarakat yang mengelola dan menjaga lingkungan dengan kearifan lokal masyarakat yang ada di Sempadan Sungai Rungan sebagai berikut :

I) Keberadaan Pasah Patahu

\section{Gambar.2} Keberadaan Pasah Patahu

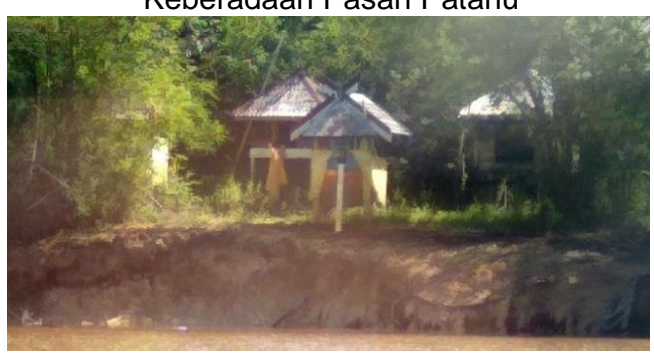

Keberadaan Pasah patahu ini akan ditemui saat memasuki daerah aliran sungai rungan jika melakukan susur sungai dari sungai kahayan. Lokasinya berada di sebelah kiri sempadan sungai rungan. Pasah petahu atau pasah keramat adalah sejenis rumah kecil yang di dalamnnya diyakini terdapat roh-roh gaib,yang kegunaannya untuk menjaga kampung dari segala bahaya yang mengancam baik dari luar maupun dari dalam.

2) Keramat Nazar

Keramat nazar yang berada di daerah aliran sungai rungan ini ditandai dengan adanya pohon dengan bendera kuning. Keramat nazar, berasal dari kata Nazar yaitu janji dari seseorang untuk melksanakan suatu jika niat, keinginnnya maupun harapnnya telah tercapai, terpenuhi atau terkabul. Masyarakat lokal memiliki aturan tidak tertulis dan semacam kaharusan untuk wajib melaksanakan segala sesuatu yang telah dinazarkan jika keinginan itu tela diterpenuhi. Pemasangan tanda umbul-umbul, bendera kunging dan putih adalah tanda bukti dari pelaknaan nazar tersebut.

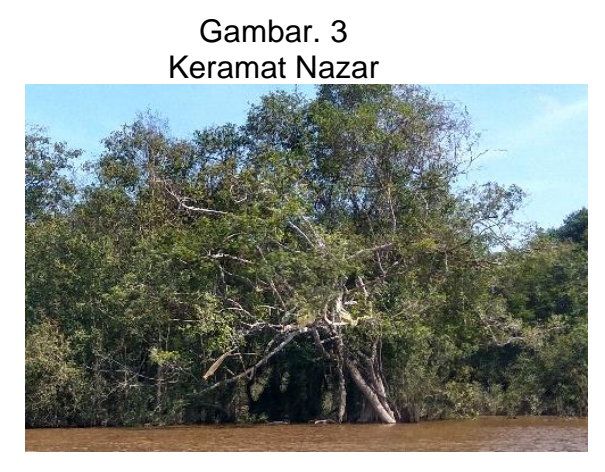

Keberadaan Pasah Patahu dan Keramat Nazar merupakan upaya mengelola dan menjaga sumber daya alam yang ada disempadan Sungai Rungan. Kearifan lokal tersebut mampu mempertahankan kondisi lingkungan dari berbagai pencemaran dan masryakat lokal mendukung kebaradaan kearifan lokal tersebut. Kemduian jika diamati lebih dalam maka kearifan lokal tersebut bisa menjadi daya tarik untuk wisata. Sehingga jika diintegrasikan dengan pengelolaan yang baik maka masyarakat lokal bisa mendapatkan sumber pendapatan dari kearifan lokal tersebut.

4. Pengelolaan dengan menggunakan teknologi yang mampu dilaksanakan oleh kondisi penghidupan setempat sehingga dapat merangsang tumbuhnya sistem intitusi pendukung (indikator teknologi).

Indikator yang kerakhir ini adalah dari sisi teknologi, bahwa masih belum dilakukan pengelolaan sumber daya alam yang memanfaatkan teknologi. Padahal dengan 
potensi sumber daya alam yang akan bernilai jual yang cukup tinggi apabila didukung dengan teknologi yang canggih pula maka akan memberikan dampak baik bagi pendapaan ekonomi masyarakat lokal.

Mengingat selama ini tidak ada produksi lokal yang populer menjadi ciri khas masyarakat lokal, maka perlu inovasi dari perpaduan kearifan lokal dan modernisasi. Salah satu contoh yang dapat dikembangkan adalah Produksi Obat Tardisional Bajakah. Mengingat teknologi farmasi saat ini sangat canggih dan berbagai akar bajakah memiliki potensi yang kuat untuk mengobati berbagai penyakit maka hal ini bisa menjadi pendapatan ekonomi masyatakat lokal dengan budidaya tanaman bajakah tersebut. Sehingga dalam hal ini perlu kajian lebih dalam mengenai hal tersebut dan memberikan potensi untuk penelitian lebih lanjut.

\section{Faktor penghambat pengelolaan sumber} daya alam untuk sumber pendapatan ekonomi masyarakat lokal di Sempadan

\section{Sungai Rungan Kota Palangka Raya}

I. Kepemilikan Pribadi

Kepemilikan pribadi yang dimaksud adalah lahan yang ada di Sempadan Sungai Rungan. Mengingat setiap jengkal lahan yang ada di sempadan sungai sudah ada kepemilikan masing-masing orang. Namun dari pengamatan mendalam yang peneliti lakukan, bahwa lahan yang ada disempadan sungai rungan masih banyak yang tidak dikelola. Dalam hal ini, ada ketidakpedulian untuk mengelola sumber daya alam secara bersamaan mengingat kepemilikan lahan adalah milik pribadi masing-masing sehingga tanggung jawab pengelolaan adalah setiap orang yang memiliki lahan tersebut.

Hal yang menjadi temuan penting dalam penelitian ini adalah banyak lahan yang tidak dikelola tersebut bukan dimiliki masyarakat lokal tapi kepemilikan oleh orang yang menginvestasikan tanahnya dan tinggal jauh dari sempadan sungai atau tinggal di pusat kota. Sehingga sumber daya alam yang ada tidak dapat memberikan manfaat ekonomi yang merata dan bahkan merugikan bagi masyarakat lokal.

2. Kelembagaan dan Non Kelembagaan

Secara kelembagaan, kelembagaan adat masih ada ditengah-tengah masyarakat namun perannya masih memiliki kebergantungan kepada lembaga pemerintah. Kemudian, kelembagaan pemerintah yang ada selama ini masih dalam tataran struktur yang rumit. Kelembagaan pemerintah terdiri dari beberapa organiasasi tersebut adalah Badan Pengelolaan Aliran Sungai Kahayan (BPDAS Kahayan), Badan Lingkungan Hidup (BLH) Kota Palangka Raya, Satpol PP, Polres Kota Palangka Raya, Dinas Pertambangan dan Energi Kota Palangka Raya serta Dinas Perikanan dan Peternakan Kota Palangka Raya. Selanjutnnya, kelembagaan Swasta yaitu pihak yang melakukan aktivitas ekonomi dengan pemanfaatan sumber daya alam. Namun aktivitas ekonomi tersebut sering kali mengabaikan dampak yang akan ditimbulkan oleh pengeksploitasian berlebihan.

Keberadaan ke tiga aktor tersebut, selama ini kurang maksimal dan belum memiliki 
sinergritas dalam pengelolaan sumber daya alam yang baik. Bahkan ketiga aktor tersebut terindikasi membentuk sebuah kelembagaan yang tidak ideal. Mengingat ketiganya saling bekerjasama untuk mengekploitasi sumber daya alam tanpa terkendali.

Sedangkan, dilihat dari sisi Non Kelembagaan. Ada rasa ketidak pedulian terhadap pengelolaan sumber daya alam yang berkelanjutan. Serta kurangnya tanggung jawab terhadap sumber daya alam yang ada untuk dikelola dengan baik. Sehingga dalam hal ini, masayrakat lokal masih kurangnnya pengetahuan terhadap sumber daya alam untuk dipergunakan sebagai sumber pendapatan ekonomi.

3. Teknologi

Selama ini masih belum dilakukan pengelolaan sumber daya alam yang memanfaatkan teknologi. Padahal dengan berbagai potensi sumber daya alam yang akan bernilai jual yang cukup tinggi apabila didukung dengan teknologi yang canggih, maka akan memberikan dampak baik bagi pendapaan ekonomi masyarakat lokal.

Mengingat selama ini tidak ada produksi lokal yang populer menjadi ciri khas masyarakat lokal, maka perlu inovasi dari perpaduan kearifan lokal dan modernisasi. Salah satu contoh yang dapat dikembangkan adalah Produksi Obat Tardisional Bajakah. Mengingat teknologi farmasi saat ini sangat canggih dan berbagai akar bajakah memiliki potensi yang kuat untuk mengobati berbagai penyakit maka hal ini bisa menjadi pendapatan ekonomi masyatakat lokal dengan budidaya tanaman bajakah tersebut. Sehingga dalam hal ini perlu kajian lebih dalam mengenai pemanfaatan teknologi tersebut dan memberikan potensi untuk penelitian lebih lanjut.

\section{KESIMPULAN}

Dari hasil penelitian dan pembahasan tentang "Analisis Pengelolaan Sumber Daya Alam sebagai Sumber Pendapatan Ekonomi Masyarakat Lokal di Sempadan Sungai Rungan Kota Palanngka Raya" maka dapat disimpulkan sebagai berikut :

I. Selama ini, pengelolaan potensi sumber daya alam yang tersedia belum dikelola dengan baik. Sehingga sumber daya alam yang belum terkelola tersebut tidak dapat memberikan sumber pendapatan ekonomi yang tetap bagi masyarakat lokal di sempadan sungai rungan Kota Palangka Raya. Padahal berbagai potensi dapat dikembangkan untuk sumber pendapatan ekonomi masyarakat lokal seperti tanaman dan tumbuhan yang dapat dibudidayakan. serta memiliki kearifan lokal untuk dijadikan wisata religi yang dapat menjadi sumber pendapatan ekonomi masyarakat lokal.

2. Faktor penghambat pengelolaan sumber daya alam untuk sumber pendapatan ekonomi masyarakat lokal di Sempadan Sungai Rungan Kota Palangka Raya yaitu I) kepemilikan pribadi atau penguasaan lahan, namun lahan tersebut bukan milik masyarakat lokal dan tidak dikelola. 2)Dari sisi Kelembagaan, selama ini kurang maksimal dan belum memiliki sinergritas dalam pengelolaan sumber daya alam yang baik. Dari sisi Non Kelembagaan, 
ada rasa ketidak pedulian terhadap pengelolaan sumber daya alam yang berkelanjutan. 3)Tidak ada dukungan dan pemanfaatan teknologi dalam pengelolaan sumber daya alam untuk sumber pendapatan ekonomi masyarakat lokal.

\section{SARAN}

1. Para pemilik lahan sebaiknya berkolaborasi dengan masyarakat lokal untuk memberdayakan lahan tersebut untuk digunakan sebagai lahan perkebunan atau budidaya tanaman lokal yang ada di sempadan sungai rungan Kota Palangka Raya. Sehingga hasil dari penggunaan lahan tersebut dapat dibagi antara pemilik lahan dan masyarakat lokal.

2. Pemerintah Kota Palangka Raya perlu melakukan inovasi untuk kemandirian pendapatan ekonomi masyarakat lokal yang tidak hanya memberikan program bantuan yang sifatnya habis pakai saja tapi memikirkan jangka panjang kehidupan masyarakat lokal dengan pemanfatan sumber daya alam. Pemerintah dalam hal ini bisa membuat program stimulun untuk kesejahteraan dan kemandirian masyarakat lokal dengan kerjasama lintas sektor seperti Dinas Ketahanan Pangan dan Pertanian, Dinas Kehutanan dan Perkebunan serta Dinas Perdagangan Kota Palangka Raya untuk memberdayakan masyarakat lokal melakukan budidaya pukis, rotan, bajakah, dll yang selama ini ada ditengah-tengah masyarakat.

3. Kepada para peneliti atau Badan Penelitian dan Pengembangan Kota Palangka Raya dapat mengkaji berbagai kearifan lokal yang bisa dimanfaatkan dan diproduksi secara masal agar menjadi Branding Kota Palangka Raya yang baru dari sektor kearifan lokal.

\section{UCAPAN TERIMA KASIH}

Puji dan syukur peneliti panjatkan kehadirat Allah SWT yang telah memberikan kemudahan kepada peneliti untuk menyusun dan menyelesaikan tesis serta jurnal ilmiah yang berjudul "Analisis Pengelolaan Sumber Daya Alam Sebagai Sumber Pendapatan Ekonomi Masyarakat Lokal di Sempadan Sungai Rungan Kota Palangka Raya". Dalam penyelesaian penulisan ini, peneliti banyak mendapatkan bantuan dari berbagai pihak. Oleh karena itu peneliti menyampaikan ucapan terima kasih setulusnya kepada :

I. Bapak Dr. H. Muhamad Yusuf, S.Sos., M.AP selaku Dekan Fakultas IImu Sosial dan IImu Politik Universitas Muhammadiyah Palangka Raya yang telah memberikan kesempatan untuk menempuh studi Magister Administrasi Publik.

2. Bapak Dr.H.M. Riban Satia, S.Sos.,M.Si pembimbing I yang telah bersedia meluangkan banyak waktu untuk memberikan bimbingan dan arahan dalam penulisan tesis ini hingga selesai.

3. Bapak Muh. Azhari,M.Si selaku dosen pembimbing Il yang memberikan arahan dalam melakukan penulisan tesis ini.

4. Bapak dan ibu yang terlibat dalam pengambilan data yakni seluruh masyarakat lokal dan segenap dinas terkait yang bersedia memberikan data dan waktunnya untuk wawancara.

5. Bapak dan ibu Dosen Pascasarjana serta pegawai FISIPOL UM Palangkaraya yang telah banyak membantu dalam hal kelancaran dan kelengkapan administrasi sehingga penulisan tesis ini bisa berjalan dengan lancar.

Akhirnya penelitian ini dapat selesai dan peneliti berharap semoga tullisan ini dapat bermanfaat bagi semua pihak, untuk menambah 
wawasan khususnya bagi mahasiswa di Program Studi Magister Administrasi Publik Universitas Muhammadiyah Palangkaraya.

\section{REFERENSI}

Chikmawati, N. F. 2013. Pengelolaan Wilayah Pesisir Dan Pulau-Pulau Kecil Di Indonesia (Dalam Perspektif Perlindungan Hukum bagi Hak-hak Ekonomi Masyarakat Tradisional). ADIL: Jurnal Hukum, 4(2), 396-4I7.

Dadie, Y. 2019. Analisis Pengelolaan Sarana Air Minum dan Jamban Keluarga di Kecamatan Delang Kabupaten Lamandau. Doctoral dissertation, STIE Indonesia Banjarmasin.

Hendarti, L. Ed. 2008. Menepis Kabut Halimun: Rangkaian Bunga Rampai Pengelolaan Sumberdaya Alam di Halimun. Yayasan Pustaka Obor Indonesia.

Listyaningrum, N., et.al. 2017. Pengelolaan Sempadan Sungai Code Sebagai Upaya Pelestarian Ekosistem Daerah Aliran Sungai Di Kota Yogyakarta Dan Sekitarnya. Seminar Nasional III : Pengelolaan Pesisir dan Daerah Aliran Sungai.

Lutfiyah, L. 20I3. Pemberdayaan Wanita Berbasis Potensi Unggulan Lokal. Sawwa: Jurnal Studi Gender, 8(2), 213-224.

Maryono, A. 2020. Pengelolaan Kawasan Sempadan Sungai. UGM PRESS.

Masyithoh, A. (2018). Pengembangan Pengelolaan Taman Bulak Kenjeran SBY. Doctoral dissertation, Universitas 17 Agustus 1945.

Moleong, L. J. 2009. Penelitian kualitatif. Jakarta: Rineka Cipta.

Mubarak, F. A. M. 2020. Analisis Pengelolaan Dana Pada Kegiatan Pengembangan Usaha Pangan Masyarakat (PUPM) Dinas Pangan Aceh. (Doctoral dissertation).

Muhammad, I. R. U. 2019. Studi keanekaragaman makrozoobentos di Sumber Taman dan Alirannya, Desa Karangsuko, Kecamatan Pagelaran, Kabupaten Malang. Doctoral dissertation. Universitas Islam Negeri Maulana Malik Ibrahim.

Prasetyo, A., \& Arifin, M. Z. 2018. Pengelolaan Destinasi Wisata yang Bekelanjutan dengan Sistem Indikator Pariwisata. Indocomp.

Punadi, P. 2018. Peran pengelolaan hasil perkebunan kopi dan kelapa oleh koperasi tani maju bersama dalam meningkatkan pendapatan petani desa Santong perspektif ekonomi syar'iah. Doctoral dissertation, Universitas Islam Negeri Mataram.

Putuhena, J. D. 2019. Pengelolaan Daerah Aliran Sungai (DAS) Dimensi Pengelolaan Berkelanjutan Di Kota Ambon. Pascasarjana Manjemen Hutan Unpatti Ambon.

Putri, E. 2018. Kemampuan Masyarakat Gayo dalam Mengelola Sumber Daya Alam. Serambi Saintia: Jurnal Sains dan Aplikasi, 6(I).

Saifullah, S. 2016. Formulasi Kebijakan Pelaksana Pelindungan Sempadan Sungai Kbupaten Sukamara. Politika: Jurnal IImu Politik, 7(I), 65-93.

Sari, D. A. P., \& Yuliani, F. 2017. Pengelolaan Taman Margasatwa Dan Budaya Kinantan Kota Bukittinggi Dalam Upaya Menuju Badan Layanan Umum Daerah. Doctoral dissertation, Riau University.

Sarnoto, A. Z. 2013. Urgensi Peningkatan Mutu Pengelolaan Pesantren Dalam Era Global. Educare, 4(I).

Satia, Riban, et.al. 2018. Pukung Pahewan, Kearifan Lokal Suku Dayak Untuk Dunia. Diva Press. Yogyakarta.

Silalahi, U. 2009. Metode Penelitian Sosial, Bandung.

Siombo, M. R. 201I. Kearifan Lokal Dalam Perspektif Hukum Lingkungan. Jurnal Hukum lus Quia lustum, 18(3), 428-443.

Suganda, dkk. 2009. Pengelolaan Lingkungan dan Kondisi Masyarakat Pada Wilayah Hilir Sungai:Makara, Sosial Humaniora, Vol. 13, No. 2, Desember 2009: I43-I53.

Sugiyono, P. 20I0. Metode Penelitian Kuantitatif, Kualitatif, Dan R\&D. Bandung: CV Alfabeta.

Teguh, M. T. 2019. Pengawasan Dewan Perwakilan Daerah Republik Indonesia terhadap kebijakan pengelolaan dan pengembangan sumber daya alam. Bachelor's thesis. Fakultas Syariah dan Hukum Universitas Islam Negeri (UIN) Syarif Hidayatullah Jakarta.

Yashinta, W., Christanto, J., \& Mei, E. T. W. 2014. Pemahaman Masyarakat Lokal terhadap Konsep Pengelolaan Kawasan Kepesisiran Terpadu di Kawasan Samas. Jurnal Bumi Indonesia, 3(3).

-----------, 2014. Rencana Konservasi Bentang Alam Kota Palangka Raya Provinsi Kalimantan Tengah. USAID \& IFACS. 